\title{
Perinatal and early adulthood factors associated with adiposity
}

\author{
Fatores perinatais e da vida adulta jovem \\ associados à adiposidade
}

${ }^{1}$ Departamento de Saúde Pública, Universidade Federal do Maranhão, São Luís, Brasil.

2 Hospital Universitário Presidente Dutra, Universidade Federal do Maranhão, São Luís, Brasil. ${ }^{3}$ Faculdade de Medicina de Ribeirão Preto, Universidade de São Paulo, Ribeirão Preto, Brasil.

Correspondence

V. M. F. Simões

Departamento de Saúde

Pública, Universidade

Federal do Maranhão.

Rua Barão de Itapary 155,

São Luís, MA 65020-070,

Brasil.

vanda@elo.com.br

\section{Abstract}

We used body mass index (BMI) and waist circumference (WC) as fat indicators to assess whether perinatal and early adulthood factors are associated with adiposity in early adulthood. We hypothesized that risk factors differ between men and women and are also different when WC is used for measuring adiposity as opposed to BMI. We conducted a longitudinal study based on a sample of 2,063 adults from the 1978/1979 Ribeirão Preto birth cohort. Adjustment was performed using four sequential multiple linear regression models stratified by sex. Both perinatal and early adulthood variables influenced adulthood BMI and WC. The associations differed between men and women and depending on the measure of abdominal adiposity (BMI or $W C)$. Living with a partner, for both men and women, and high fat and alcohol intake in men were factors that were consistently associated with higher adulthood BMI and WC levels. The differences observed between sexes may point to different lifestyles of men and women, suggesting that prevention policies should consider gender specific strategies.

Adiposity; Obesity; Young Adult; Waist Circumference
Vanda Maria Ferreira Simões 1,2

Marco Antonio Barbieri 3

Antonio Augusto Moura da Silva 1

Rosangela Fernandes Lucena Batista 1

Maria Teresa Seabra Soares de Britto e Alves 1

Viviane Cunha Cardoso 3

Helma Jane Ferreira Veloso 1

Heloisa Bettiol 3

\section{Introduction}

Obesity has become a severe worldwide public health problem. It is considered one of the major risk factors linked to the development of cardiovascular diseases such as hypertension, diabetes and dyslipidemia, and is associated with increased mortality ${ }^{1}$. Over the last decades, Brazil, like several other Latin American countries, has undergone a rapid demographic, epidemiological and nutritional transition $2,3,4$, resulting in an increased prevalence of overweight and obesity in the country 5,6 .

Studies have shown that individuals with lower levels of schooling and income have a higher prevalence of overweight and obesity 7,8 . However, in Brazil, a higher prevalence of obesity has been observed in women with lower levels of schooling and in men with higher levels of schooling 4 . It has also been found that married men and women have a higher prevalence of obesity 9,10,11.

Prevalence of obesity is higher in children born to primiparous women 12. Experimental studies on animals have also demonstrated that maternal parity influences size at birth, postnatal growth and body composition 13 . Studies have also revealed a relationship between higher weight at birth and risk of obesity in adolescence and in adult life 4,14 .

The body mass index (BMI) has been internationally recommended as an indicator of 
body adiposity but is limited because it does not distinguish between excess muscle, fat or bone mass 15. Waist circumference (WC) is used in population studies as an indicator of adiposity for the following reasons: it is associated with the occurrence of cardiovascular diseases 16; results obtained using this method highly correlate with those of laboratory methods for assessing body composition 17 ; it is one of the simplest methods to use and is highly reproducible $18,19,20$. Some studies have suggested that the combined use of the two measures (BMI and WC) improves identification of the risk of cardiovascular diseases 21 .

The objective of the present study was to determine the association between specific perinatal factors (BMI at birth, socioeconomic status and number of gestations) and early adulthood factors (socioeconomic status, marital status, smoking, alcohol consumption and daily fat intake) and adiposity in adult life. We hypothesized that risk factors differ between men and women and when WC, as opposed to BMI, is used to measure adiposity. The study was conducted among the young population (aged 23 to 25 years) of a city with high per capita income in a middle-income country.

\section{Material and methods}

The present study arose during the fourth stage of a prospective longitudinal birth cohort study, which included infants born in the municipality of Ribeirão Preto, State of São Paulo, Brazil between June 11978 and May 311979 22,23,24. In 2005, Ribeirão Preto, located 320km northeast of the city of São Paulo in the Southeast Region of Brazil, had 543,885 inhabitants 25 and an area of $642 \mathrm{~km}^{2}$.

\section{Population and sample}

A total of 9,067 liveborn neonates delivered in hospitals in Ribeirão Preto between June 11978 and May 311979 (98\% of all liveborn babies) participated in the study. For the follow-up of the cohort, babies whose mothers were not originally from Ribeirão Preto and not resident in the city at the time of childbirth were excluded from the study. Of the 6,973 liveborn babies whose mothers were residents of the city, 6,827 were single births and 146 were twins. Of the 6,827 single births, 246 died within the first year of life 26 and 97 died before reaching the age of 20 (a total of 343 deaths) 27.

In 2002, after excluding multiples, 6,484 cohort members residing in the city were eligible for follow-up. Due to a high urbanization rate of $99.6 \%$ (Brazilian Institute of Geography and Statistics, 2000), the search was performed only in the urban zone and 5,665 individuals (87.4\%) were located. The city was divided into four geoeconomic areas: poor, middle-poor, middle-rich and rich. Using the geo-economic characterization of the city 28 as a basis, one out of every three residents of the same geographic area was randomly selected, contacted and invited to participate in the follow-up study. During this process, 705 individuals had to be randomly replaced due to refusal (209), imprisonment (31), death before the age of 20 (34), and failure to attend the interview (431). Therefore, a total of 2,063 young adults effectively participated in the study, corresponding to $31.8 \%$ of the original sample (Figure 1). Details of the methodology used by this study have been published elsewhere 29 . The project was approved by the Research Ethics Committee of the University Hospital, Faculty of Medicine of Ribeirão Preto, University of São Paulo (Hospital Universitário, Faculdade de Medicina de Ribeirão Preto, Universidade de São Paulo HCFMRP-USP).

\section{Instruments and variables}

Structured questionnaires were conducted through face-to-face interviews undertaken with the mother after childbirth and with the adults between the ages of 23 and 25 years.

The following variables were studied at birth: birth weight and length, birth BMI (calculated as weight, in $\mathrm{kg}$, divided by height, in $\mathrm{m}$, squared), preterm birth (defined as $<37$ weeks gestational age, measured from the first day of the last normal menstrual period as reported by the mother); maternal level of schooling in number of years of study (0-4, 5-8, 9-11 and $\geq 12$ years); maternal smoking (categorized as yes, regardless of the number of cigarettes smoked per day, and no); maternal marital status (partner or no partner), and number of gestations (1, 2 to 3 , and $\geq 4$ ). Anthropometric measurements were taken using hospital pediatric table scales (with $10 \mathrm{~g}$ precision) tested and calibrated on a weekly basis. The infant was weighed immediately after birth. Birth length was measured with the infant in the supine position using an anthropometric instrument specially made for the project and available in all hospitals. The BMI was used instead of the ponderal index that is used as an indicator of thinness at birth, because it is a better measure of adiposity 30 .

The following variables were studied in the adults: current occupation of the head of the family 23, categorized as non-manual, skilled manual, 
Some of the characteristics of liveborn individuals from the 1978/1979 cohort evaluated in the fourth stage of the study at the age of 23 to 25 years.

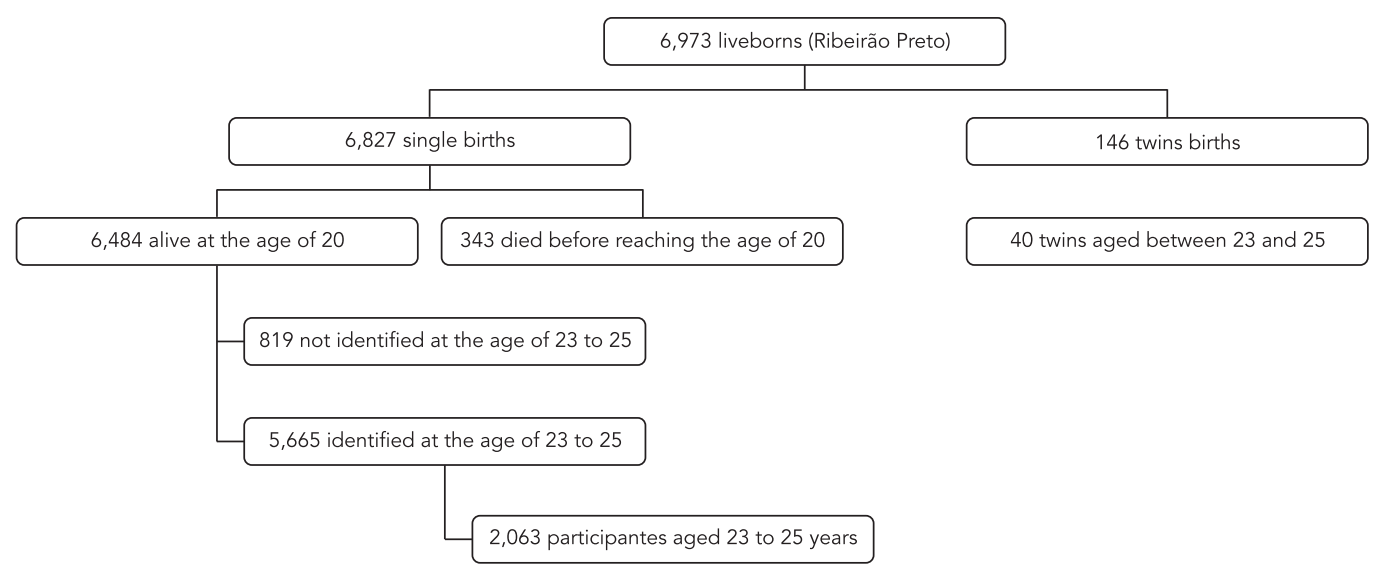

semi-skilled manual, unskilled manual and other (people undergoing training or students, unemployed, retired and housewives); level of schooling categorized as number of years of study (0-4, 5-8, 9-11 and $\geq 12$ years); marital status (partner or no partner), smoking habits during the last month (non-smoker, ex-smoker and smoker: $<5, \geq 5$ cigarettes per day). Alcohol consumption during the last month was assessed in g/day, with $>31.1$ / day being considered "high" and $\leq 31.1 \mathrm{~g} /$ day being considered "low". This cut-off point, to separate low and high alcohol consumption, was defined because above this level consumption is considered excessive 31 . A comparison between low and high consumption was made because low and moderate alcohol consumption has been associated with lower risk of cardiovascular diseases 32 . Daily fat intake was measured and analyzed as a continuous variable. Information on alcohol consumption and daily fat intake was obtained using a food frequency questionnaire (FFQ) on the "habitual" diet regarding food intake over the previous 12 months. The FFQ was based on a questionnaire validated for use with the Japanese-Brazilian community of São Paulo 33. The BMI was calculated using the formula: $\mathrm{BMI}=$ weight $(\mathrm{kg}) /$ height $(\mathrm{m})^{2}\left(\mathrm{BMI}=\mathrm{W} / \mathrm{H}^{2}\right)$. WC was considered to be high when $>102 \mathrm{~cm}$ for men and $>88 \mathrm{~cm}$ for women 34 . Anthropometric measurements (weight, height and WC) were performed by trained personnel using standardized techniques 35 , with the subject barefoot and wearing light clothes. The instruments used were a periodically calibrated precision scale, anthropometric instruments for measurements with the subject standing or sitting, and an inextensible measuring tape.

\section{Statistical analysis}

A sample of 783 individuals from both sexes was necessary in order to obtain a linear regression model coefficient equal to 0.10 , with $80 \%$ power at significance level of 0.05 . We opted to stratify the sample by gender because in Brazil the variables associated with obesity differ between men and women 6,11 .

The response variables used were adulthood BMI and WC. BMI at birth was used as a continuous variable. Sequential adjustment was performed with four models stratified by sex using a hierarchical approach: the first model - adjustment for BMI at birth and preterm birth; the second model - adjustment for birth variables such as maternal smoking, level of schooling, age, marital status and number of gestations, as well as BMI at birth and preterm birth; the third model - adjustment for adulthood variables such as level of schooling, occupation, marital status, smoking, alcohol consumption and daily fat intake, as well as BMI at birth and preterm birth; the fourth model - adjustment for all variables.

The statistical model used for analysis was multiple linear regression. This model requires residuals with normal distribution with zero 
mean and constant variance. Since this assumption was not satisfied, the bootstrap method was applied to the regression model. The bootstrap confidence interval ( $\mathrm{BCa}$ ) of $95 \%$ was adopted by the present study, and the percentiles of bootstrap distribution and the percentile interval were also used. The advantage of the $B C a$ is that it generates more accurate confidence limits than the intervals obtained by the percentile method. The results were obtained using Stata 8.0 software (Stata Corp., College Station, USA).

\section{Results}

With regard to birth weight $(p=0,618)$, birth length $(p=0,507)$ and maternal age at delivery ( $p=0,065$ ), no differences were found between those that participated and those that did not participate in the follow-up study. In the group that participated in the follow-up study there was a greater proportion of women $(p=0,004)$, a greater number of preterm births $(p=0,037)$, a greater proportion of heads of family employed in high-skilled occupations $(p<0,001)$, a greater proportion of mothers with $\geq 5$ years of schooling $(\mathrm{p}<0,001)$ and a greater number were married $(\mathrm{p}<0,001)$ (Table 1$)$.

Of a total of 2,063 individuals that participated in the study, $51.8 \%$ were females and $48.2 \%$ males. Almost two thirds of the sample $(63.3 \%)$ self-reported themselves as white, $84.5 \%$ had $\geq 9$ years of schooling, $34.3 \%$ were skilled or semi-skilled manual workers, $23.8 \%$ were not economically active, $21 \%$ were employed in a non-manual occupation, $32 \%$ were married and $27.2 \%$ had children. The family income of more than half of the sample (53\%) was three to 10 minimum wages and approximately $10 \%$ of individuals studied were from low income families ( $<3$ minimum wages).

The results showed significant differences between the sexes regarding anthropometric characteristics, alcohol consumption and smoking habits (Table 2). A higher proportion of men were overweight $(30.3 \%$ compared to $17.7 \%$ of women). The prevalence of obesity was similar for both genders $(12.8 \%$ of men and $11.1 \%$ of women). Alcohol consumption was lower among women (58.3\%). "High" alcohol consumption (>31.1g/day) in men was greater than in women (32.8\% vs. $8.7 \%)$. Women also presented lower levels of tobacco use compared to males (13.9\% vs. $20.8 \%$ ). With respect to daily fat intake, approximately $25 \%$ of the total sample reported that they consumed $40 \mathrm{~g}$ or more of fat per day. However, fat intake did not differ significantly between the sexes.
When adulthood BMI was used as a response variable, no association between adult BMI and BMI at birth was found for either of the sexes using the first model, adjusted for preterm birth (Table 3).

In the second model, adjusted for preterm birth plus birth variables, among women, for every $1 \mathrm{~kg} / \mathrm{m}^{2}$ increase in BMI at birth there was a $0.26 \mathrm{~kg} / \mathrm{m}^{2}$ increase in adulthood BMI. The adulthood BMI of women with mothers with lower levels of schooling at the time of birth showed an increase of between 1.6 and $1.8 \mathrm{~kg} / \mathrm{m}^{2}$. For women whose mothers had two or three gestations, adulthood BMI showed a decrease of $1.22 \mathrm{~kg} / \mathrm{m}^{2}$. Among men, there was an association between BMI at birth and adulthood BMI (Table 3).

In the third model, adjusted for preterm birth and for adulthood variables, among women, for every $1 \mathrm{~kg} / \mathrm{m}^{2}$ increase in BMI at birth there was an $0.27 \mathrm{~kg} / \mathrm{m}^{2}$ increase in adulthood BMI. The adulthood BMI of women whose head of family was employed in a semi-skilled occupation showed an increase of $1.4 \mathrm{~kg} / \mathrm{m}^{2}$. The adulthood BMI of women who lived with a partner showed an increase of $1.72 \mathrm{~kg} / \mathrm{m}^{2}$. The adulthood BMI of men who lived with a partner showed an increase of $0.9 \mathrm{~kg} / \mathrm{m}^{2}$. The adulthood BMI of men who consumed large amounts of alcohol showed an increase of $1.15 \mathrm{~kg} / \mathrm{m}^{2}$ (Table 3).

In the fourth model, adjusted for all variables, among women, for every $1 \mathrm{~kg} / \mathrm{m}^{2}$ increase in BMI at birth there was a $0.28 \mathrm{~kg} / \mathrm{m}^{2}$ increase in adulthood BMI. The adulthood BMI of women whose mothers had had two or three gestations, showed a decrease of $0.97 \mathrm{~kg} / \mathrm{m}^{2}$. Among women whose head of family was employed in a semiskilled occupation, adulthood BMI showed an increase of $1.13 \mathrm{~kg} / \mathrm{m}^{2}$. The adulthood BMI of women who lived with a partner showed an increase of $1.47 \mathrm{~kg} / \mathrm{m}^{2}$. The adulthood BMI of men who lived with a partner also showed an increase of $0.93 \mathrm{~kg} / \mathrm{m}^{2}$. In men whose alcohol consumption was $\geq 31.1 \mathrm{~g} /$ day, adulthood BMI showed an increase of $1.1 \mathrm{~kg} / \mathrm{m}^{2}$. In men, for every $1 \% \mathrm{in}$ crease in daily fat intake, there was a $0.05 \mathrm{~kg} / \mathrm{m}^{2}$ increase in adulthood BMI (Table 3).

Using WC as the response variable, for the first model, adjusted for preterm birth, there was no association between BMI at birth and adulthood WC in either of the sexes (Table 4). In the second model, adjusted for preterm birth and other birth variables, the WC of adult women whose mothers had lower levels of schooling at the time of delivery was 3.3 to $4.0 \mathrm{~cm}$ larger. There was no association between any other variable using this model (Table 4).

With respect to the third model, adjusted for preterm birth and adulthood variables, adult- 
Table 1

Comparison of the characteristics of the cohort at birth (1978/1979) with those of the participants in the fourth phase of the study (2002/2004).

\begin{tabular}{|c|c|c|c|c|}
\hline Variables & $\begin{array}{c}\text { Initial population } \\
\text { 1978/1979 * }\end{array}$ & $\begin{array}{l}\text { Individuals not } \\
\text { interviewed in } \\
2002 / 2004 \text { ** }\end{array}$ & $\begin{array}{c}\text { Individuals } \\
\text { interviewed in } \\
2002 / 2004 \star \star \star\end{array}$ & p-value \\
\hline & n (\%) & n (\%) & n (\%) & \\
\hline Sex & & & & 0.004 \\
\hline Female & $3,185(49.1)$ & $2,117(47.9)$ & $1,068(51.8)$ & \\
\hline Male & $3,299(50.9)$ & $2,304(52.1)$ & $995(48.2)$ & \\
\hline Birth weight (g) & & & & NS \\
\hline$<2,500$ & $380(5.9)$ & $252(5.7)$ & $128(6.2)$ & \\
\hline $2,500-2,999$ & $1,349(20.8)$ & $935(21.1)$ & $414(20.1)$ & \\
\hline $3,000-3,499$ & $2,644(40.8)$ & $1,796(40.6)$ & $848(41.1)$ & \\
\hline $3,500-3,999$ & $1,673(25.8)$ & $1,149(26.0)$ & $524(25.4)$ & \\
\hline$\geq 4,000$ & $438(6.7)$ & $289(6.6)$ & $149(7.2)$ & \\
\hline Birth length (cm) & & & & NS \\
\hline$<47$ & $723(11.1)$ & $498(11.3)$ & $225(10.9)$ & \\
\hline $47-49$ & $1,612(24.9)$ & $1,109(25.1)$ & $503(24.4)$ & \\
\hline $49-51$ & $2,664(41.1)$ & $1,830(41.4)$ & $834(40.4)$ & \\
\hline $51-53$ & $1,170(18.0)$ & 775 (17.5) & $395(19.2)$ & \\
\hline$\geq 53$ & $281(4.3)$ & $186(4.2)$ & $95(4.6)$ & \\
\hline Unknown & $34(0.6)$ & $23(0.5)$ & $11(0.5)$ & \\
\hline Preterm birth & & & & 0.037 \\
\hline Yes & $388(6.0)$ & $246(5.6)$ & $142(6.9)$ & \\
\hline No & $6,096(94.0)$ & $4,175(94.4)$ & $1,921(93.1)$ & \\
\hline $\begin{array}{l}\text { Occupation of the head of } \\
\text { the family }\end{array}$ & & & & $<0.001$ \\
\hline Non-manual & $1,079(16.6)$ & $740(16.7)$ & $339(16.4)$ & \\
\hline $\begin{array}{l}\text { Skilled and semi-skilled } \\
\text { manual }\end{array}$ & $3,685(56.9)$ & $2,420(54.8)$ & $1,265(61.3)$ & \\
\hline $\begin{array}{l}\text { Unskilled manual or } \\
\text { unemployed }\end{array}$ & $1,514(23.3)$ & $1,115(25.2)$ & $399(19.3)$ & \\
\hline Unknown & $206(3.2)$ & $146(3.3)$ & $60(3.0)$ & \\
\hline Maternal schooling (years) & & & & $<0.001$ \\
\hline$\geq 12$ & $655(10.1)$ & $440(10.0)$ & $215(10.4)$ & \\
\hline $5-11$ & $2,483(38.3)$ & $1,595(36.1)$ & $888(43.0)$ & \\
\hline $0-4$ & $3,186(49.1)$ & $2,266(51.2)$ & $920(44.6)$ & \\
\hline Unknown & $160(2.5)$ & $120(2.7)$ & $40(2.0)$ & \\
\hline Maternal age (years) & & & & NS \\
\hline $20-35$ & 4,998 (77.1) & $3,372(76.3)$ & $1,626(78.8)$ & \\
\hline$\geq 35$ & $537(8.3)$ & $366(8.3)$ & $171(8.3)$ & \\
\hline$<20$ & $889(13.7)$ & $635(14.4)$ & $254(12.3)$ & \\
\hline Unknown & $60(0.9)$ & $48(1.0)$ & $12(0.6)$ & \\
\hline Maternal marital status & & & & $<0.001$ \\
\hline Married & $5,375(82.9)$ & $3,565(80.6)$ & $1,810(87.7)$ & \\
\hline Cohabiting & $613(9.5)$ & $481(10.9)$ & $132(6.4)$ & \\
\hline Non-cohabiting & $422(6.5)$ & $317(7.2)$ & $105(5.1)$ & \\
\hline Unknown & $74(1.1)$ & $58(1.3)$ & $16(0.8)$ & \\
\hline
\end{tabular}

NS: not significant.

* $N=6,484$ excluding 343 deaths;

$\star * N=4,421$;

$\star \star \star N=2,063$. 
Anthropometric characteristics and alcohol, tobacco and fat consumption according to sex. Ribeirão Preto, São Paulo State, Brazil, 2002/2004.

\begin{tabular}{|c|c|c|c|}
\hline \multirow[t]{2}{*}{ Variables/Categories } & \multicolumn{2}{|c|}{ Sex } & \multirow[t]{2}{*}{$p$-value * } \\
\hline & Male n (\%) & Female $\mathrm{n}(\%)$ & \\
\hline BMI $\left(\mathrm{kg} / \mathrm{m}^{2}\right)$ & & & $<0.001$ \\
\hline Thin $(<18.5)$ & $26(2.6)$ & $92(8.6)$ & \\
\hline Adequate (18.5-24.9) & $537(54.0)$ & $664(62.2)$ & \\
\hline Overweight (25.0-29.9) & $302(30.3)$ & $189(17.7)$ & \\
\hline Obese $(\geq 30.0)$ & $127(12.8)$ & $119(11.1)$ & \\
\hline Not determined & $3(0.3)$ & $4(0.4)$ & \\
\hline Waist circumference & & & 0.066 \\
\hline Normal & 882 (88.7) & 918 (86.0) & \\
\hline High & $112(11.2)$ & 149 (13.9) & \\
\hline Smoking habit in the last month & & & $<0.001$ \\
\hline Yes & $207(20.8)$ & 148 (13.9) & \\
\hline No & $788(79.2)$ & $920(86.1)$ & \\
\hline Alcohol consumption in the last month & & & $<0.001$ \\
\hline Yes & $756(76.0)$ & $623(58.3)$ & \\
\hline No & $239(24.0)$ & $445(41.7)$ & \\
\hline Alcohol consumption (g/day) ** & & & $<0.001$ \\
\hline No & $194(19.6)$ & $370(34.9)$ & \\
\hline$\leq 31.1$ & $470(47.6)$ & $599(56.5)$ & \\
\hline$>31.1$ & $324(32.8)$ & $92(8.7)$ & \\
\hline Fat consumption in diet (\%) & & & 0.950 \\
\hline$<30.0$ & $122(12.3)$ & $134(12.6)$ & \\
\hline $30.0-39.9$ & $630(63.3)$ & $669(62.6)$ & \\
\hline$\geq 40.0$ & $243(24.4)$ & $265(24.8)$ & \\
\hline
\end{tabular}

BMI: body mass index.

* Chi-square test;

** Based on a food-frequency questionnaire.

Table 3

Estimates of the coefficients and $95 \%$ confidence intervals $(95 \% \mathrm{Cl})$ for body mass index (BMI) in adult life adjusted for birth and adult life variables in four sequential models. Ribeirão Preto, São Paulo State, Brazil, 2002/2004.

\begin{tabular}{lcccc}
\hline Variables & \multicolumn{2}{c}{ Female } & \multicolumn{2}{c}{ Male } \\
& Coefficient & $95 \% \mathrm{Cl} *$ & Coefficient & $95 \% \mathrm{Cl}$ * \\
\hline $\begin{array}{l}\text { Model 1 } \\
\text { BMl at birth (continuous) }\end{array}$ & 0.223 & $-0.011 ; 0.443$ & 0.149 & $-0.042 ; 0.329$ \\
Model 2 & & & & \\
$\quad$ BMl at birth (continuous) & 0.259 & $0.008 ; 0.491$ & 0.160 & $0.028 ; 0.327$ \\
$\quad$ Maternal schooling (years of study) & & & & \\
$\quad 0-4$ & 1.621 & $0.516 ; 2.548$ & -0.486 & $-1.410 ; 0.327$ \\
5-8 & 1.818 & $0.653 ; 2.803$ & 0.711 & $-0.276 ; 1.702$ \\
9-11 & 0.598 & $-0.566 ; 1.622$ & 0.181 & $-0.882 ; 1.136$ \\
$\geq 12$ & Reference & & & \\
\hline
\end{tabular}

(continues) 
Table 3 (continued)

\begin{tabular}{|c|c|c|c|c|}
\hline \multirow[t]{2}{*}{ Variables } & \multicolumn{2}{|c|}{ Female } & \multicolumn{2}{|c|}{ Male } \\
\hline & Coefficient & $95 \% \mathrm{Cl}$ * & Coefficient & $95 \% \mathrm{Cl}$ * \\
\hline \multicolumn{5}{|l|}{ Model 2} \\
\hline \multicolumn{5}{|l|}{ Number of maternal pregnancies } \\
\hline 1 & -0.765 & $-1.915 ; 0.433$ & -0163 & $-1.252 ; 0.782$ \\
\hline $2-3$ & -1.220 & $-2.221 ;-0.268$ & -0.065 & $-1.027 ; 0.761$ \\
\hline$\geq 4$ & Reference & & & \\
\hline \multicolumn{5}{|l|}{ Model 3} \\
\hline BMI at birth (continuous) & 0.268 & $0.016 ; 0.491$ & 0.147 & $-0.032 ; 0.343$ \\
\hline \multicolumn{5}{|l|}{ Current occupation of family head } \\
\hline Non-manual & Reference & & & \\
\hline Skilled manual & 0.698 & $-0.048 ; 1.391$ & -0.640 & $-1.309 ; 0.063$ \\
\hline Semiskilled manual & 1.393 & $0.572 ; 2.283$ & -0.258 & $-1.059 ; 0.606$ \\
\hline Unskilled manual & 0.544 & $-0.384 ; 1.527$ & -0.387 & $-1.259 ; 0.437$ \\
\hline Others ** & 0.101 & $-1.234 ; 2.512$ & 0.352 & $-1.083 ; 2.020$ \\
\hline \multicolumn{5}{|l|}{ Marital status of the interviewee } \\
\hline Without a companion & Reference & & & \\
\hline With a companion & 1.719 & $1.010 ; 2.338$ & 0.910 & $0.247 ; 1.567$ \\
\hline \multicolumn{5}{|c|}{ Alcohol consumption by the interviewee (g/day) } \\
\hline $\operatorname{Low}(<31.1)$ & -0.091 & $-0.807 ; 0.568$ & 0.540 & $-0.274 ; 1.191$ \\
\hline $\operatorname{High}(\geq 31.1)$ & 0.289 & $-0.801 ; 1.461$ & 1.148 & $0.284 ; 1.880$ \\
\hline None & Reference & & & \\
\hline \multicolumn{5}{|l|}{ Model 4} \\
\hline BMI at birth (continuous) & 0.277 & $0.035 ; 0.495$ & 0.162 & $-0.028 ; 0.348$ \\
\hline \multicolumn{5}{|l|}{ Number of maternal pregnancies } \\
\hline 1 & -0.545 & $-1.690 ; 0.624$ & -0.104 & $-1.102 ; 0.828$ \\
\hline $2-3$ & -0.965 & $-1.989 ;-0.006$ & 0.0461 & $-0.838 ; 0.909$ \\
\hline$\geq 4$ & Reference & & & \\
\hline \multicolumn{5}{|l|}{ Current occupation of family head } \\
\hline Non-manual & Reference & & & \\
\hline Skilled manual & 0.495 & $-0.257 ; 1.269$ & -0.655 & $-1.354 ; 0.102$ \\
\hline Semiskilled manual & 1.133 & $0.210 ; 1.981$ & -0.279 & $-1.149 ; 0.600$ \\
\hline Unskilled manual & 0.215 & $-0.764 ; 1.226$ & -0.302 & $-1.192 ; 0.656$ \\
\hline Others ** & 0.117 & $-1.402 ; 2.471$ & 0.329 & $-1.067 ; 2.032$ \\
\hline \multicolumn{5}{|l|}{ Marital status of the interviewee } \\
\hline Without a companion & Reference & & & \\
\hline With a companion & 1.466 & $0.786 ; 2.152$ & 0.927 & $0.258 ; 1.622$ \\
\hline \multicolumn{5}{|c|}{ Alcohol consumption by the interviewee (g/day) } \\
\hline Low $(<31.1)$ & -0.069 & $-0.789 ; 0.609$ & 0.414 & $0.368 ; 1.089$ \\
\hline $\operatorname{High}(\geq 31.1)$ & 0.228 & $-0.964 ; 1.522$ & 1.110 & $0.215 ; 1.899$ \\
\hline None & Reference & & & \\
\hline$\%$ fat ingested per day (continuous) & 0.039 & $-0.018 ; 0.099$ & 0.050 & $0.001 ; 0.100$ \\
\hline
\end{tabular}

* Bootstrap BCa confidence interval; Model 1: adjusted for preterm birth; Model 2: adjusted for birth variables (maternal smoking, schooling, age, marital status and number of gestations, as well as BMI at birth and preterm birth); Model 3: adjusted for adult life variables (occupation of the family head, marital status, smoking, alcohol consumption and percent fat in the diet, as well as BMI at birth and preterm birth); Model 4: adjusted for all birth and adult life variables;

** Others = persons under training or students, unemployed, retired, and housewives. 
Estimates of the coefficients and $95 \%$ confidence intervals $(95 \% \mathrm{Cl})$ for waist circumference $(\mathrm{WC})$ in adult life adjusted for birth and adult life variables in four sequential models. Ribeirão Preto, São Paulo State, Brazil, 2002/2004.

\begin{tabular}{|c|c|c|c|c|}
\hline \multirow[t]{2}{*}{ Variables } & \multicolumn{2}{|c|}{ Females } & \multicolumn{2}{|c|}{ Males } \\
\hline & Coefficient & $95 \% \mathrm{Cl}$ * & Coefficient & $95 \% \mathrm{Cl}$ * \\
\hline \multicolumn{5}{|l|}{ Model 1} \\
\hline BMI at birth (continuous) & 0.210 & $-0.349 ; 0.735$ & 0.447 & $-0.034 ; 0.900$ \\
\hline \multicolumn{5}{|l|}{ Model 2} \\
\hline \multicolumn{5}{|l|}{ Maternal schooling (years) } \\
\hline $0-4$ & 4.088 & $1.300 ; 6.459$ & -1.382 & $-3.801 ; 0.827$ \\
\hline $5-8$ & 3.371 & $0.702 ; 5.801$ & 2.269 & $-0.378 ; 4.951$ \\
\hline $9-11$ & 0.623 & $-2.160 ; 3.001$ & 0.483 & $-2.194 ; 3.078$ \\
\hline$\geq 12$ & Reference & & & \\
\hline \multicolumn{5}{|l|}{ Model 3} \\
\hline \multicolumn{5}{|l|}{ Occupation of family head } \\
\hline Non-manual & Reference & & & \\
\hline Skilled manual & 1.730 & $-0.053 ; 3.447$ & -1.259 & $-2.981 ; 0.438$ \\
\hline Semiskilled manual & 4.002 & $1.948 ; 5.990$ & -0.332 & $-2.415 ; 1.767$ \\
\hline Unskilled manual & 1.531 & $-0.702 ; 3.741$ & -0.552 & $-2.883 ; 1.689$ \\
\hline Others ** & 1.589 & $-1.734 ; 9.311$ & 0.478 & $-2.850 ; 4.870$ \\
\hline \multicolumn{5}{|c|}{ Marital status of the interviewee } \\
\hline Without companion & Reference & & & \\
\hline With a companion & 3.376 & $1.825 ; 4.859$ & 2.483 & $0.847 ; 4.337$ \\
\hline \multicolumn{5}{|c|}{ Smoking habit of the interviewee (cigarettes) } \\
\hline Non-smoker & Reference & & & \\
\hline Ex-smoker & 2.948 & $0.061 ; 7.521$ & -0.006 & $-2.112 ; 2.429$ \\
\hline$<5$ & 2.360 & $-0.342 ; 6.324$ & -0.204 & $-3.263 ; 3.318$ \\
\hline$\geq 5$ & 0.907 & $-1.591 ; 3.899$ & 0.311 & $-1.747 ; 2.715$ \\
\hline \multicolumn{5}{|c|}{ Alcohol consumption by the interviewee ( $\mathrm{g} /$ day) } \\
\hline $\operatorname{Low}(<31.1)$ & -0.475 & $-2.134 ; 1.067$ & 1.901 & $0.032 ; 3.783$ \\
\hline $\operatorname{High}(\geq 31.1)$ & 0.367 & $-2.364 ; 3.150$ & 3.467 & $1.252 ; 5.632$ \\
\hline None & Reference & & & \\
\hline \multicolumn{5}{|l|}{ Model 4} \\
\hline \multicolumn{5}{|l|}{ Maternal schooling (years) } \\
\hline $0-4$ & 2.101 & $-1.041 ; 4.653$ & -0.828 & $-3.298 ; 1.728$ \\
\hline $5-8$ & 1.808 & $-0.866 ; 4.210$ & 2.790 & $0.123 ; 5.600$ \\
\hline $9-11$ & -0.388 & $-3.073 ; 2.253$ & 1.108 & $-1.527 ; 3.696$ \\
\hline$\geq 12$ & Reference & & & \\
\hline \multicolumn{5}{|l|}{ Occupation of family head } \\
\hline Non-manual & Reference & & & \\
\hline Skilled manual & 1.223 & $-0.710 ; 2.943$ & -0.933 & $-3.090 ; 0.993$ \\
\hline Semiskilled manual & 3.194 & $1.136 ; 5.239$ & -0.220 & $-2.545 ; 1.870$ \\
\hline Unskilled manual & 0.534 & $-1.764 ; 3.033$ & 0.047 & $-2.392 ; 2.482$ \\
\hline Others ** & 1.303 & $-2.131 ; 8.352$ & 0.352 & $-3.073 ; 4.230$ \\
\hline \multicolumn{5}{|c|}{ Marital status of the interviewee } \\
\hline Without a companion & Reference & & & \\
\hline With a companion & 2.799 & $1.158 ; 4.350$ & 2.528 & $0.824 ; 4.317$ \\
\hline
\end{tabular}


Table 4 (continued)

\begin{tabular}{|c|c|c|c|c|}
\hline \multirow[t]{2}{*}{ Variables } & \multicolumn{2}{|c|}{ Females } & \multicolumn{2}{|c|}{ Males } \\
\hline & Coefficient & $95 \% \mathrm{Cl}$ * & Coefficient & $95 \% \mathrm{Cl}$ * \\
\hline \multicolumn{5}{|l|}{ Model 4} \\
\hline \multicolumn{5}{|c|}{ Smoking habit of the interviewee (cigarettes) } \\
\hline Non-smoker & Reference & & & \\
\hline Ex-smoker & 3.442 & $0.209 ; 7.413$ & 0.102 & $-2.171 ; 2.706$ \\
\hline$<5$ & 2.192 & $-0.984 ; 6.236$ & -0.305 & $-3.312 ; 3.416$ \\
\hline$\geq 5$ & 0.752 & $-1.715 ; 3.741$ & 0.534 & $-1.753 ; 2.793$ \\
\hline \multicolumn{5}{|c|}{ Alcohol consumption by the interviewee ( $\mathrm{g} /$ day) } \\
\hline Low $(<31.1)$ & -0.354 & $-2.016 ; 1.195$ & 1.530 & $-0.406 ; 3.519$ \\
\hline $\operatorname{High}(\geq 31.1)$ & 0.215 & $-2.709 ; 3.535$ & 3.413 & $1.209 ; 5.460$ \\
\hline None & Reference & & & \\
\hline$\%$ fat ingested per day (continuous) & 0.047 & $-0.086 ; 0.181$ & 0.139 & $0.012 ; 0.269$ \\
\hline
\end{tabular}

* Bootstrap BCa confidence interval; Model 1: adjusted for preterm birth; Model 2: adjusted for birth variables (maternal smoking, schooling, age, marital status and number of gestations, as well as BMI at birth and preterm birth); Model 3: adjusted for adult life variables (occupation of the family head, marital status, smoking, alcohol consumption and percent fat in the diet, as well as BMI at birth and preterm birth); Model 4: adjusted for all birth and adult life variables;

** Others: persons under training or students, unemployed, retired, and housewives.

hoodWC was $4.0 \mathrm{~cm}$ larger in women from households where the head of the family was employed in a semi-skilled occupation at the time of birth. Adulthood WC was 2.9 larger in ex-smokers. Adult hood WC was $3.38 \mathrm{~cm}$ and $2.48 \mathrm{~cm}$ larger in women and men respectively living with a partner, compared to men and women living without a partner. Adulthood WC of men who consumed alcohol was 1.9 to $3.5 \mathrm{~cm}$ larger than that of men who did not consume alcohol (Table 4).

Regarding the fourth model, adjusted for all variables, there was no association between BMI at birth and adulthood WC in either of the sexes. Adulthood WC was larger in women from households where the head of the family was employed in a semi-skilled manual occupation $(3.19 \mathrm{~cm})$, women living with a partner $(2.80 \mathrm{~cm})$ and women who were ex-smokers $(3.44 \mathrm{~cm})$. Adulthood WC was larger in men whose mothers had 5 to 8 years of schooling at the time of birth $(2.79 \mathrm{~cm})$, men living with a partner $(2.53 \mathrm{~cm})$ and men who consumed $\geq 31.1 \mathrm{~g}$ alcohol per day $(3.41 \mathrm{~cm})$. For every $1 \%$ increase in fat intake among men, there was a $0.14 \mathrm{~cm}$ increase in adulthood WC (Table 4).

\section{Discussion}

\section{Main findings}

An association between BMI at birth and adulthood BMI was found only among women. Adult- hood BMI was larger in women living with a partner and from households whose head of the family was employed in a semi-skilled manual occupation and lower in women born to mothers who had had two to three gestations. Adulthood BMI was larger in men living with a partner, who consumed large amounts of alcohol and had a large fat intake.

No association between BMI at birth and adulthood WC was found using the sequential adjustment models. Adulthood WC was generally larger among women living with a partner, belonging to a household whose head of the family was employed in a semiskilled occupation and who were ex-smokers. Adulthood WC was generally larger in men whose mother had 5 to 8 years of schooling at the time of birth, living with a partner and who consumed large amounts of alcohol and fat.

\section{BMI at birth}

The association detected between greater BMI at birth and greater adulthood BMI confirms the findings of other studies that have proved the association between greater birth weight and greater adulthood BMI 36,37. However, in the present study, this association was only observed in women and the effect was small, probably due to the young age of the cohort. Previous systematic reviews have found consistent associations between birth weight and obesity in childhood and adulthood 38,39 and there is no suggestion 
that such an association is limited to the female sex as found here. The different results for men and women may be explained by health behavior or by differences in in utero programming mechanisms.

No association was observed between BMI at birth and adulthood WC in men or women. This may be because the accumulation of abdominal fat occurs at a later age and therefore the effect of BMI at birth on adulthood WC manifests itself in later adult life. In a study conducted in the United Kingdom, greater birth weight was associated with a larger WC at 43 years of age only in men 40.

\section{Number of gestations}

While women born to mothers who had had two or three gestations presented lower adulthood BMI compared to those whose mothers had had four or more gestations (a fact that was not observed in men), no association was found between number of gestations and adulthood WC. Recent studies have emphasized the importance of parity in the development of adipose tissue. This suggests that first born offspring have an increased capacity for adipogenesis, which may be an important factor determining later adiposity ${ }^{13}$. Reynolds et al. 12 demonstrated higher body fat percentages among men and women born to primiparous women. The association between primiparity and offspring adiposity and late metabolic disease was also described in models used to study animals 13. In our study, however, body mass index was higher only among women born from mothers who had had four or more gestations. Any gender affected association between the number of gestations and later offspring adiposity might be explained by differential gender effects of programming due to interactions between biological mechanisms and life-style factors.

\section{Marital status}

Velásquez-Meléndez et al. 11 demonstrated a higher prevalence of obesity and overweight among individuals living with a spouse. In the present study, living with a partner was associated with higher BMI and WC values in adulthood among men and women, thus demonstrating a consistent association between having a partner and greater body adiposity.

\section{Socioeconomic status in adulthood}

Studies in developed countries have shown that higher socioeconomic status is associated with a lower risk of obesity for both men and women 7,8 . Studies conducted in Brazil have reported that, among women, lower levels of schooling are associated with higher levels of obesity, whereas among men a higher prevalence of obesity is associated with higher socioeconomic status 4,6. Velásquez-Meléndez et al. 11 demonstrated that there is a higher prevalence of obesity and overweight among women with less than 9 years of schooling. According to Veloso \& Silva 9, lower levels of schooling among women were associated with a higher prevalence of abdominal obesity and excess weight, whereas among men higher levels of schooling were associated with a greater prevalence of excess weight. In the present study, having a medium socioeconomic status (defined as coming from a household where the head of the family is employed in a manual semi-skilled occupation) was associated with a higher BMI and larger WC only among women. It is possible that women that have a medium socioeconomic status enjoy greater access to higher energy and lower cost foods than women of a low socioeconomic status, and that women having a higher socioeconomic status can afford more expensive low energy dense foods. Han et al. 41 reported that Dutch women who had not completed high school are almost three times more likely to have abdominal adiposity than women with higher levels of schooling.

\section{Socioeconomic status during childhood}

Goldani et al. 42 demonstrated an association between lower levels of maternal schooling at childbirth ( $<8$ years) and higher BMI among males aged 18 years. These results were not replicated by the present study, since lower levels of maternal schooling during childhood ( $<8$ years) was associated with greater BMI and WC in adulthood among women but not among men.

\section{Other factors}

It is well known that adiposity increases in people who give up smoking ${ }^{43}$. A study conducted in Brazil demonstrated that ex-smokers of both sexes had greater mean WC values compared to smokers and non-smokers ${ }^{44}$. In the present study, however, no association of this nature was found in men and, in women, being an ex-smoker was only associated with a larger adulthood WC and not with a higher adulthood BMI.

The influence of certain behavioral factors on adiposity has also been subject to study. Dallongeville et al. 45 demonstrated an association between alcohol consumption and larger WC, regardless of BMI, in both sexes. Donadussi et al. 46 
demonstrated an association between high total fat intake and greater abdominal circumference in men. In the present study, men who consumed a high quantity of alcohol and had a high fat diet $(\geq 40 \%)$ presented higher BMI and greater WC values.

\section{Strengths and limitations}

One of the strengths of the present study is that it comprises a longitudinal population-based investigation involving a young population in a middle-income country undergoing nutrition transition. It is known that a significant increase in the prevalence of obesity and glucose intolerance has been observed in middle-income countries which have experienced rapid changes in socioeconomic conditions and where food scarcity has given way to greater availability and abundance within a short period of time 47,48,49,50.

The present study is limited due to losses in the cohort during the first year after birth when infant mortality rates were still high, especially among small for gestational age infants. Many of the lighter and smaller newborns did not sur-

\section{Resumo}

Utilizou-se o indice de massa corporal (IMC) e a circunferência de cintura (CC) para avaliar se alguns fatores perinatais e da vida adulta se associam com adiposidade na vida adulta jovem. Trabalhou-se com a hipótese de que os fatores de risco diferem entre homens e mulheres e também são diferentes quando a CC é utilizada como medida de adiposidade em vez do IMC. Realizou-se estudo longitudinal baseado em 2.063 pessoas da coorte de nascimentos de 1978/1979 de Ribeirão Preto, São Paulo, Brasil. Foi feito ajuste sequencial em quatro modelos de regressão linear múltipla, estratificados por sexo. Tanto variáveis do início da vida como atuais interferiram no IMC e na CC. As associações foram diferentes para homens e mulheres, e também quando se considerou o IMC ou a CC. Homens e mulheres que vivem com companheira $(o) e$ homens que têm consumo elevado de gordura e álcool apresentam maiores valores de IMC e de CC. As diferenças encontradas podem apontar para estilos de vida diferentes de homens e mulheres, sugerindo que as políticas de prevenção também precisam traçar estratégias diferenciadas segundo gênero.

Adiposidade; Obesidade; Adulto Jovem; Circunferência da Cintura vive 26 , limiting the analysis of the relationship between birth weight and disease during adult life. Furthermore there were some differences between subjects followed-up and those not interviewed in 2002/2004. Follow-up rates were lower in the case of males, particularly those engaged in manual occupations, not born preterm, with low levels of schooling and unmarried.

\section{Conclusions}

Both early and current life variables influenced BMI and WC in adulthood. Associations differed inmen and women and were also different between BMI and WC. The most consistent associations were that men and women living with a partner and men that have a high intake of fat and alcohol present higher BMI and WC values in adulthood. The difference detected between genders may indicate some differences in life style between men and women, suggesting that preventive policies should also incorporate specific strategies for each sex.

\section{Contributors}

V. M. F. Simões participated in the study design, the literature review, data analysis, the discussion of results and was responsible for the drafting and revision of the final version of this paper. M. A. Barbieri, A. A. M. Silva and $\mathrm{H}$. Bettiol participated in study design, data analysis, discussion of results and revised the final version of this paper. R. F. L. Batista, M. T. S. S. B. Alves and V. C. Cardoso participated in data analysis, the discussion of results and revised the final version of this paper. H. J. F. Veloso collaborated in the discussion of results and revised the final version of this paper.

\section{Acknowledgments}

Research was supported by FAPESP (n. 93/0525-0, 97/09517-1 and 00/09508-7), CNPq (n. 523474/96-2 and 520664/98-1), and Fundação de Auxílio ao Ensino, Pesquisa e Assistência do HCFMRP-USP. 


\section{References}

1. World Health Organization. Obesity: preventing and managing the global epidemic. Geneva: World Health Organization; 1997.

2. Post CL, Victora CG, Barros FC, Horta BL, Guimarães PRV. Desnutrição e obesidade infantis em duas coortes de base populacional no Sul do Brasil: tendências e diferenciais. Cad Saúde Pública 1996; 12 Suppl 1:49-57.

3. Wang Y, Monteiro CA, Popkin BM. Trends of obesity and underweight in older children and adolescents in the United States, Brazil, China, and Russia. Am J Clin Nutr 2002; 75:971-7.

4. Monteiro POA, Victora CG, Barros FC, Monteiro LMA. Birth size, early childhood growth, and adolescent obesity in a Brazilian birth cohort. Int J Obes 2003; 27:1274-82.

5. Batista Filho M, Rissin A. Nutritional transition in Brazil: geographic and temporal trends. Cad Saúde Pública 2003; 19 Suppl 1:S181-91.

6. Monteiro CA, Conde WL, Popkin BM. Independent effects of income and education on the risk of obesity in the Brazilian adult population. J Nutr 2001; 131:881S-6.

7. Woo J, Leung SSF, Ho SC, Sham A, Lam TH, Janus ED. Influence of educational level and marital status on dietary intake, obesity and other cardiovascular risk factors in a Hong Kong Chinese population. Eur J Clin Nutr 1999; 53:461-7.

8. Wardle J, Waller J, Martin JJ. Sex differences in the association of socioeconomic status with obesity. Am J Public Health 2000; 92:1299-304.

9. Veloso HJF, Silva AAM. Prevalence and factors associated with abdominal obesity and excess weight among adults from Maranhão, Brazil. Rev Bras Epidemiol 2010; 13:400-12.

10. Gigante DP, Barros FC, Post CLA, Olinto MTA. Prevalência de obesidade em adultos e seus fatores de risco. Rev Saúde Pública 1997; 31:236-46.

11. Velásquez-Meléndez G, Pimenta AM, Kac G. Sobrepeso e obesidade em Belo Horizonte (MG). Rev Panam Salud Pública 2004; 16:308-14.

12. Reynolds RM, Osmond C, Phillips DIW, Godfrey KM. Maternal BMI, parity, and pregnancy weight gain: influences on offspring adiposity in young adulthood. J Clin Endocrinol Metab 2010; 95:5365-9.

13. Hyatt MA, Keisler DH, Budge H, Symonds ME. Maternal parity and its effect on adipose tissue deposition and endocrine sensitivity in the postnatal sheep.J Endocrinol 2010; 204:173-9.

14. Seidman DS, Laor A, Gale R, Stevenson DK, Danon YL. A longitudinal study of birth weight and being overweight in late adolescence. Am J Dis Child 1991; 145:782-5.

15. Dietz WH, Bellizzi MC. Introduction: the use of body mass index to assess obesity in children. Am J Clin Nutr 1999; 70 Suppl:123S-5.

16. Dyer AR, Liu K, Walsh M, Kiefe C, Jacobs Jr. DR, Bild DE. Ten-year incidence of elevated blood pressure and its predictors: The CARDIA Study. Coronary Artery Risk Development in (Young) Adults. J Hum Hypertens 1999; 13:13-21.
17. Lean MEJ, Han TS, Deurenberg P. Predicting body composition by densitometry from simple anthropometric measurements. Am J Clin Nutr 1996; 63:4-14.

18. Pouliot MC, Després JP, Lemieux S, Moorjani S, Bouchard C, Tremblay A, et al. Waist circumference and abdominal sagittal diameter: best simple anthropometric indexes of abdominal visceral adipose tissue accumulation and related cardiovascular risk in men and woman. Am J Cardiol 1994; 73:460-8.

19. Goran MI, Ball GD, Cruz ML. Obesity and risk of type 2 diabetes and cardiovascular disease in children and adolescents. J Clin Endocrinol Metab 2003; 88:1417-27.

20. Shen W, Chen J, Albu J, Pi-Sunyer X, Lewis CE, Grunfeld C, et al. Waist circumference correlates with metabolic syndrome indicators better than percentage fat. Obesity 2006; 14:727-36.

21. Janssen I, Katzmarzyk PT, Srinivasan SR, Chen W, Malina R, Bouchard C, et al. Combined influence of body mass index and waist circumference on coronary artery disease risk factors among children and adolescents. Pediatrics 2005; 115: 1623-30.

22. Barbieri MA, Gomes UA, Barros Filho AA, Bettiol $\mathrm{H}$, Almeida LEA, Silva AAM. Saúde perinatal em Ribeirão Preto, SP, Brasil: a questão do método. Cad Saúde Pública 1989; 5:376-87.

23. Bettiol H, Barbieri MA, Gomes UA, Andrea M, Goldani MZ, Ribeiro ERO. Saúde perinatal em Ribeirão Preto, SP, Brasil, 1994: metodologia e algumas características da população estudada. Rev Saúde Pública 1998; 32:18-28.

24. Cardoso VC, Simões VMF, Barbieri MA, Silva AAM, Bettiol H, Alves MTSSB, et al. Profile of three Brazilian birth cohort studies in Ribeirão Preto, SP and São Luís, MA. Braz J Med Biol Res 2007; 40: 1165-76.

25. Fundação Sistema Nacional de Análises de Dados. Informações dos municípios paulistas (São Paulo em dados). http://www.seade.gov.br (accessed on 19/Jul/2005).

26. Almeida LEA, Barbieri MA, Gomes UA, Reis PM, Chiaratti TM, Vasconcellos V, et al. Peso ao nascer, classe social e mortalidade infantil em Ribeirão Preto, São Paulo. Cad Saúde Pública 1992; 8:190-8.

27. Oliveira ZAR, Bettiol H, Barbieri MA, Gutierrez MRP, Azenha VM. Factors associated with infant and adolescence mortality. J Epidemiol Community Health 2004; 58:107-8.

28. Goldani MZ, Barbieri MA, Bettiol H, Barbieri MR, Tomkins A. Infant mortality rates according to socioeconomic status in a Brazilian city. Rev Saúde Pública 2001; 35:256-61.

29. Barbieri MA, Bettiol H, Silva AAM, Cardoso VC, Simões VMF, Gutierrez MRP, et al. Health in early adulthood: the contribution of the 1978/79 Ribeirão Preto birth cohort. Braz J Med Biol Res 2006; 39:1041-55. 
30. Tamim H, Beydoun H, Itani M, Khogali M, Chokr I, Yunis KA, et al. Predicting neonatal outcomes: birthweight, body mass index or ponderal index? J Perinat Med 2004; 32:509-13.

31. Costa JSD, Silveira MFS, Gazalle FK, Oliveira SS, Hallal PC, Menezes AMB. Heavy alcohol consumption and associated factors: a population-based study. Rev Saúde Pública 2004; 38:284-91.

32. Farchi G, Fidanza F, Giampaoli S, Mariotti S, Menotti A. Alcohol and survival in the Italian rural cohort of the Seven Countries Study. Int J Epidemiol 2000; 29:667.

33. Molina MC, Bettiol H, Barbieri MA, Silva AAM, Conceição SIO, Dos-Santos JE. Food consumption by young adults living in Ribeirão Preto, SP, 2002/2004. Braz J Med Biol Res 2007; 40:1257-66.

34. Expert Panel on Detection, Evaluation ant Treatment of High Blood Cholesterol in Adults. Executive summary of the Third Report of the National Cholesterol Education Program (NCEP). Expert Panel on Detection, Evaluation ant Treatment of High Blood Cholesterol in Adults (Adult Treatment Panel III). JAMA 2001; 285:2486-97.

35. Cameron N. The measurement of human growth. Sydney: Croom Helm; 1984.

36. Sorensen HT, Sabroe S, Rothman KJ, Gillman M, Fischer P, Sorensen TJA. Relation between weight and length at birth and body mass index in young adulthood: cohort study. BMJ 1997; 315:1137.

37. Rasmussen F, Johansson M. The relation of weight and ponderal index at birth to body mass index and overweight among 18-year-old males in Sweden. Eur J Epidemiol 1998; 14:373-80.

38. Parsons TJ, Power C, Logan S, Summerbell CD. Childhood predictors of adult obesity: a systematic review. Int J Obes Relat Metab Disord 1999; 23 Suppl 8:S1-107.

39. Martins EB, Carvalho MS. Associação entre peso ao nascer e o excesso de peso na infância: revisão sistemática. Cad Saúde Pública 2006; 22:2281-300.

40. Kuh D, Hardy R, Chaturvedi N, Wadsworth MEJ. Birth weight, childhood growth and abdominal obesity in adult life. Int J Obes 2002; 26:40-7.
41. Han TS, Bijnen FCH, Lean MEJ, Seidell JC. Separate associations of waist and hip circumference with lifestyle factors. Int J Epidemiol 1998; 27: 422-30.

42. Goldani ZM, Haeffner LSD, Agranonik M, Barbieri MA, Bettiol H, Silva AAM. Do early life factors influence body mass index in adolescents? Braz J Med Biol Res 2007; 40:1231-6.

43. Reas DL, Nygard JF, Sorensen T. Do quitters have anything to lose? Changes in body mass index for daily, never, and former smokers over an 11-year period (1990-2001). Scand J Public Health 2009; 37:774-7.

44. Castanheira M, Olinto MTA, Gigante DP. Associação de variáveis sócio-demográficas e comportamentais com a gordura abdominal em adultos: estudo de base populacional no Sul do Brasil. Cad Saúde Pública 2003; 19 Suppl 1:S55-65.

45. Dallongeville J, Marécaux N, Ducimetière P, Ferrières J, Arveiler K, Bingham A, et al. Influence of alcohol consumption and various beverages on waist girth and waist-to-hip ratio in a sample of French men and women. Int J Obes Relat Metab Disord 1998; 22:1178-83.

46. Donadussi C, Oliveira AF, Fatel ECS, Dichi JB, Dichi I. Dietary fats and measures of adiposity in military policemen. Rev Nutr PUCCAMP 2009; 22:847-55.

47. Popkin BM. The nutrition transition and its health implications in lower-income countries. Public Health Nutr 1998; 1:5-21.

48. Adair LS. Pre- and postnatal exposures and later growth and developmental outcomes. In: Johnston FE, Zemel B, Eveleth PB, editors. Human growth in context. London: Smith-Gordon Nishimura; 1999. p. 313-20.

49. Victora CG, Barros FC. Commentary: the catch-up dilemma - relevance of Leitch's "low-high" pig to child growth of developing countries. Int J Epidemiol 2001; 30:217-20.

50. Robinson R. The fetal origins of adult disease. BMJ 2001; 322:375-6.

Submitted on $24 / \mathrm{Jul} / 2011$

Final version resubmitted on $02 /$ Dec/2011

Approved on 15/Mar/2012 